\title{
The "Violence" of the Canon: Revisiting Contemporary Notions of Canonical Forms
}

\author{
Colby Dickinson \\ Loyola University Chicago, cdickinson1@luc.edu
}

Follow this and additional works at: https://ecommons.luc.edu/theology_facpubs

Part of the Religious Thought, Theology and Philosophy of Religion Commons

Author Manuscript

This is a pre-publication author manuscript of the final, published article.

\section{Recommended Citation}

Dickinson, Colby. The "Violence" of the Canon: Revisiting Contemporary Notions of Canonical Forms. Horizons, 40, 1: , 2013. Retrieved from Loyola eCommons, Theology: Faculty Publications and Other Works, http://dx.doi.org/10.1017/hor.2013.39

This Article is brought to you for free and open access by the Faculty Publications and Other Works by Department at Loyola eCommons. It has been accepted for inclusion in Theology: Faculty Publications and Other Works by an authorized administrator of Loyola eCommons. For more information, please contact ecommons@luc.edu. c) (i) $\Theta$

This work is licensed under a Creative Commons Attribution-Noncommercial-No Derivative Works 3.0 License. Copyright (c) College Theology Society 2013 
The "violence" of the canon: revisiting contemporary notions of the canonical

\begin{abstract}
The historical conditions surrounding the processes of forming a canon are rarely examined directly, yet it is these processes which govern over the realm of religious representations and identity constructions. In light of recent critical scholarship, it is imperative to address theologically the role that the canon plays within a religious tradition. This essay demonstrates the cultural necessity of canonical forms despite their "monotheistic tendency" to subdivide the world into binary oppositions. By utilizing a scale of violence to determine the impact of the canonical form upon culture this essay offers an account of canons and their role in forming religious identities over and beyond the violence they are said to provoke. Through this clarification, an alternative perspective of canons can emerge that reveals the violence at the core of culturalcanonical norms, thus providing a valuable distinction between differing (violenceconcealing or violence-revealing) canonical forms.
\end{abstract}




\section{The "Violence" of the Canon: Revisiting Contemporary Notions of Canonical Forms}

\section{Introduction}

There is often a lurking suspicion in the popular imagination that the Catholic Church holds a vast repository of ancient documents that threaten to destroy the Church's authority if they ever reached the light of day. These non-canonical documents, as the stories generally go, were deemed heretical at some point in time and nearly destroyed, and are now allegedly stored deep within the secret vaults of the Vatican's archives, so that their testimony - their contradictory witness to the normative historical recordcould be confidently suppressed and the Church could go about dominating history as it deems fit. ${ }^{1}$ The truth, of course, is that the Catholic Church has at times engaged in tactics such as these, though such acts of erasure and censure, one hopes, are nearing their end. The tantalizing power of these "repressed" narratives eventually coming to light, however, is often enough to provoke the desires of those who feel their stories too are marginalized and in need of mainstream representation within the given media of their community. Such desires, for example, have been behind those calls to admit the Bible's hegemonic status among other texts and likewise to open the canon of scripture to other "non-canonical" works. ${ }^{2}$

What this all-too-contemporary tale does not take into account, however, are the dynamics which govern the nature of canonical (and hence scriptural) representations themselves, the historical evolutions that mark scripture's core coming-to-be - those

processes termed canonicity. ${ }^{3}$ It is these processes themselves that offer us an insight into how any such "repressed narrative" might be capable of finding its own story reflected, not only in the ever-changing (more or less) open literary canons of the world, 
but in the sacred, closed form of the canonical as well — a text that, by definition, is certainly capable of containing the opposed tensions of a desire for law and a call for justice simultaneously within its own pages. This is not to suggest, however, that every closed or sacred canon performs such an act; indeed, this study intends to produce a series of criteria centered on the principle of violence - as developed through the works of Jan Assmann and René Girard—by which various sacred canons might be evaluated and therefore in some sense rendered distinguishable from one another.

Canons, in their earliest forms, were a refinement of cultural and religious archives, a solid body of normative "texts" transmitted from one generation to another in order to identify and shape a given community. Such canons were either orally transmitted or written, and could be used for either cultural or religious purposes (or both at the same time, as was often the case in the ancient world). However, it was only the latter purposes (and even then generally in written form only) that led to the formation of a sacred scripture as we know it today in its western monotheistic forms.

The question that the creation of such normative structures raises, however, is this: what are we to make of the place of such selected texts within a particular culture given that other texts, indeed other archives, were not chosen to identify the community? Are such texts (like the early Gnostic writings, for example) simply to be burned or buried in the sands of history? Should (or even could) they be placed alongside the more normative canonical texts? In other words, the basic question is whether or not selected canonical texts are capable of being distinguished from one another with regard to their relationship to non-canonical, archival, and "excessive" texts. That is, do some canons welcome their non-canonical counterparts within the same archive (or particular 
tradition) while others support an institution that would suppress, distort or discard them? What violences are canonical texts able to enclose within themselves in order to achieve canonical status? Or can such a normative status be achieved otherwise than by violent means? And what would such a canonical form look like?

In essence, I argue in this essay that the canonical form can be seen to fluctuate along a sliding scale of normative texts which serve to either (1) deal with their noncanonical counterparts and hence acknowledge their omission as necessary to the formation of normative texts (the definition of the "violence" which a canon could be said to perform), or (2) conceal or repress those very same violent acts. It is with the former, however, that a new avenue for understanding the canonical (and hence scriptural) form is opened up. Such an understanding in fact could be considered as "non-violent" (or perhaps simply "less" violent) insofar as it is able to provide narration for those persons whose stories are repressed in their particular socio-cultural contexts. Such canonical texts could possibly also lead to further contestations against the violence of unnecessary repressions or exclusions. This form of a canon, if openly demonstrated, can provide a way for socially marginalized figures to re-write their own personal or communal narratives within the stories of that particular (often sacred) canon and thereby find avenues for the representation of their socially-constituted identities. This is so because their stories of marginalization and repression will have already been present in the canonical text as stories which themselves reveal the violences of repression. In this fashion, revelation becomes structurally bound to the canonical form itself and as such truly becomes an ongoing well-spring of justice found in canonical scriptural forms, as I hope to make clear in what follows. This characteristic could moreover be said to be 
guaranteed by the processes of canonicity themselves which continue long past the formation of an actual canon.

This distinction between canonical forms becomes even more important to make when one stops to consider recent sustained criticisms levied against the monotheistic worldview brought about by the Judeo-Christian canon. ${ }^{4}$ Such critiques are often directed toward religious scriptures, though, as we will soon see, these critical voices also indicate that a general call toward opening the canonical form is not isolated to the recent past or a contemporary popularized cultural imagination. They demonstrate how the issue with canons is one that extends beyond religious scripture and toward a perspective on canonical texts on the whole. Accordingly, there needs to be an engagement with these dynamics from within a more contemporary theological framework if the canonical form is to be shown to be necessary for religious-cultural signification and the basis of religious identity formation in general, and not simply as a source of an unnecessary and detestable violence.

In what follows, I hope to show how it is no coincidence that many scholars locate the site of a particular (monotheistic) violence within the nature of canons themselves. ${ }^{5}$ This is so because the establishment of the canon actually does function as a fundamental act of violence insofar as its construction and representation of the "other" is thoroughly invested in the processes of marking boundaries — of separating oneself from others (traditionally those subject to another canonical culture). This feature is considered in fact to be a mark of a canon's "non-translatability", as we will see, a trait that renders the canon less fluid in cultural terms and causes canons to be firmly rooted in a particular religious or national context. ${ }^{6}$ I will show, moreover, that this is a necessity 
for identity formation and representation in general, something which is inherently connected to the establishment and prominence of cultural canonical forms. It would seem, then that there are only those canons that conceal the violence they perform - and thus multiply its effects and aftereffects—or those that disclose their proximity to violence and thereby offer an ever-increasing sense of justice a chance to flourish instead. ${ }^{7}$ And it is precisely by allowing these general characteristics of canons to unfold before us that we will begin to see just how relevant the specifically Judeo-Christian scriptures can be amidst so many competing canons today.

\section{On monotheism and violence}

It has long been recognized within scholarship on the canonical form that the canon itself has what James Sanders refers to as a "monotheizing tendency"-a habit of dividing existent reality into binary forms. This is a fact often responsible for the clichéd stereotyping of the "us-versus-them" mentality, though such a characterization does bear

a certain political truth. ${ }^{8}$ From this perspective, it should come as no surprise that reactions to the biblical canon's partitioning of reality into such demarcated spaces have been frequent and often harsh. ${ }^{9}$ One of the more recently influential and thus exemplary studies to put forward a general condemnation of the canonical form is Regina Schwartz's The Curse of Cain, a polemically-structured critique of the monotheistic (biblical) canon. For Schwartz, the biblical narrative became in fact the foundation for "Western culture's central myth of collective identity." Utilizing the linked concepts of "scarcity" and "oneness" (associated with the exclusivity of a monotheistic worldview), 
throughout her analysis she opposes them to the preferred notions of "generosity", "plentitude" and "multiplicity" (with their polytheistic undertones). By providing this contrast, she embarks upon a quest to eradicate the seeds of what she sees as collective violence embodied in the deity who would promote a relative frenzy of ownership for scarce resources (e.g. land, food, spouses, etc) in favor of one who would ensure peace through an offer of generosity and an embracing of differences which resist becoming permanent and remain nomadic. In this scenario, the former is found in the god of monotheism; the latter, in the polytheistic impulses of the Near East that were quickly overshadowed by their powerful opponents.

Accordingly, she posits that whereas scarcity provokes a response focused upon establishing greater definition in terms of political and sexual identity (thus giving shape to subsequent notions of what is to be considered as "familial" or "natural"), plentitude resists such limited characterizations, eschewing the "preoccupations" of a narrative that sets people at odds with one another. ${ }^{10}$ Like those critics of the canonical form who would argue for a return to a more egalitarian polytheistic worldview (as idealistic as it might appear at times), Schwartz contemplates a similar gesture in her condemnation of this monotheistic ideological identification. In the end, she reasons, scarcity thinking would seem to impose a need for transcendence that ultimately ends up creating a distant and inaccessible deity. ${ }^{11}$ Latent in this critique is a profound call to a sort of immanent, polytheistic worldview, one that opposes the politically powerful transcendence of a monotheistic outlook on the world.

What remains central to Schwartz's critique of monotheism and is of heightened interest to this study is the illustrative position of the canonical form. Her depiction of 
the Hebrew canon's formation as a response to the impending crisis of a loss of national identity prioritizes the fixation of communal boundaries and the rigidity of a Jewish identity constructed upon the seminal event of Exile. ${ }^{12}$ It was at this precise moment, in her view, that the fluid and evolving memories of the Jewish people were unjustly subjected to a process of canonization that effectively closed what should have otherwise remained open to the multiple views more prominently circulating within ancient Israel. For Schwartz, normative religious structures were much looser at this time in history, and the creation of a canonical scripture and tradition actually undermined the polyvalent Judaisms present at the time. The Hebrew canon thus served in a very literal sense as an ideological constraint imposed upon otherwise often widely divergent narratives. In turn, this creation of a canon subsequently gave rise to the canonical form's resistance to "translatability", perhaps the defining feature of its "monotheizing tendencies." ${ }^{13}$ Instead of many voices crossing many boundaries, people within such a canonical community were forced to remain within a shell that could be seen as either protective or isolating.

Employing the twin witnesses of the ancient prophet Jeremiah, with his insistence upon "rewriting scripture", and contemporary psychological insights concerning an individual's inability to ever fully provide closure to their own personal narrative, Schwartz concludes her critique with a call to open the biblical canon to new stories beyond the canonical boundary, and thereby also to the truth which enriches and proliferates within the multiplicity of narratives possible. ${ }^{14}$ Such is the only just way forward, she contends, and her conclusions have the potential to strike a deep chord with contemporary western culture. 
Despite the obvious popular appeal which Schwartz's claims hold, her account of the western monotheistic canonical form is not without its counter-claims - or at least subtle nuances that push us in other directions of thought. Another somewhat similar voice can be found in the work of Mark S. Smith, who offers a critique that runs parallel to most of Schwartz's and yet starkly registers the opposite conclusion. Smith, in fact, provides a richer look into monotheism's encapsulation of earlier polytheistic beliefs. $\mathrm{He}$ diverges from Schwartz in his conclusions concerning the overall status and role of the canonical form within a given religious context. ${ }^{15}$

Smith locates the three primary trends of monotheism's incorporation of polytheism as (1) a convergence, or the assimilation of all the other deities into one, (2) a differentiation, or denying the other gods an existence and (3) a reinterpretation of the older polytheistic stories into monotheistic ones. ${ }^{16}$ Each of these maneuvers could be classified as a tactic of re-writing previously existent canonical traditions in a bid to create a more stabilized identity under the threat of an immanent historical crises, much as Schwartz had argued. Indeed, for the most part, Smith's critique parallels that of Schwartz, even going so far as to offer monotheism as an interpretive lens of reality that shaped Israel's worldview in a particular nationalistic (ideological) manner. ${ }^{17}$

Smith departs from this general critique, however, through his deepening of the notion of a collective memory within the text. It is this feature, in his view, that serves to reflect God's revelation, "what God selected to be remembered and forgotten of God's relationship to Israel and the world," thus turning any perceived ideological script into a divine directive. ${ }^{18}$ This, it should be carefully noted, is at once an effort to acknowledge a canon's selective reading of history and yet also a way to illustrate how the processes 
of canonicity cannot be so quickly dismissed as an inherently reactionary form of violence. Such a reading of the canonical form might be seen as a critique of those who would jettison the significance attached to any subsequent historical development of particular faith traditions and their relation to the canonical form. Smith's decisive rendering of the biblical canonical narrative as a divine choice likewise places him among those who would see the integrity of the canon maintained, though the way we think about it is altered. ${ }^{19}$ In other words, in Smith's estimation there is indeed a violence performed by the canonical form (or, one might say, by God) if a canon is to be perceived as sacred revelation at all. It is a necessary violence that grants religious identity, akin to the marks of circumcision or tattooing made upon the body. This is the price of religious and cultural signification - a reality that the canonical form directly signifies.

The sustained capacity for religious and cultural signification found in a canon forms the basis for what Smith, in another context, calls the "non-translatable core" of the biblical canon, or that which allowed the early Hebrew people to resist the colonial powers of empire. ${ }^{20}$ By offering this reading and thereby furthering our understanding of how and why a canon might actually be utilized, Smith is able to illustrate a direct line of continuity between the biblical critique of empire and contemporary post-colonial critiques, at least insofar as both clearly draw from and yet resist the dominant cultural forms of a colonial power. ${ }^{21}$ The opening of this argument toward the political implications of canonical forms, especially with regard to the violence said to proceed from them, is crucial to expressing Smith's overall concern toward those who would like to free the canon from its "non-translatable core", something which Smith goes to great lengths to stress cannot be done without rendering the biblical canon bereft of its 
identifying (signifying) power. Canons, by this count, are not just about narrowing the multiplicity of narratives available within a given community; they are also about protecting a community's identity when faced with external threats concerning its dissolution.

What becomes uniquely discernable in Smith's account is the fundamentally intertwined nature of both cultural and religious canons with the political and historical contexts in which they are born. As I will contend, cultural and religious canons exert a social power aligned with a conception of politics as being essentially a polarized division: us versus them. As such, canons tend to reflect the core identifying features of a given political landscape. To transcend canonical, normative divisions would effectively be a claim to transcend politics as we know it. Such a configuration of the political and the canonical can also help explain why there is an often insurmountable difficulty encountered when trying to transcend the particularities of a given political paradigm (its "non-translatability" so to speak).

In Smith's view and in other accounts that I will mention, the biblical canon utilizes its essential trait of non-translatability precisely as a powerful and necessary source of cultural signification so that communal identifications might develop as a form of "counter-resistance" to the types of violence imposed upon a particular canonical community. Canonicity is therefore a move to posit "non-translatability" as being (though at times obscurely) the cornerstone of a (pre)formed cultural-canonical identity, something that can never really be suspended between two different canons and that can only be altered through a "conversion" from one cultural-canonical signifier to another. 
To summarize the point, I would suggest that the validity of these varied contentions on either side of the debate, despite their differences, rests upon the reality of whether or not they correspond to a fuller understanding of the dimensions and consequences of the canonical form as a whole. That is, we must ask ourselves whether certain canons promote violence while others seek to lessen its effects. One might further inquire whether all canonical forms could be said to perform an act of violence which could otherwise have been avoided and replaced by a more diffuse, seemingly primordial (though perhaps vaguely stated) multiplicity devoid of any canonical form or (here following Smith) whether this violence of the canonical form simply alters our perception of the text itself, creating the blatant, though perhaps necessary, entrance of an often terrifying God.

Resolving this impasse is not easy to do. As I will argue, both sides in some sense also fail to account for the desires of canonicity which exist over and beyond any particular manifestation of the canonical form (especially in a religious sense). The fact that these critical appraisals of Judaism's monotheistic origins share so much in common in their overall analysis, diverting only in the manner through which they draw their conclusions from the material given, is partial evidence that there is no single answer to the problem of imposing canonical norms when one assesses the situation of the canonical form historically.

In order to provide a constructive account of canons, what is necessary is a more proper distinction of the tensions that arise within canons themselves, such as what I will examine later in this essay. In this way, these particular tensions might begin to reveal how the presumption of regarding a canonical "monotheizing" text as an inherently 
violent text worth disregarding lacks a more rigorous account of the multiple forms of violence culturally present to us today also in canonical form and already indebted to the various and competing canons present within any given society. This repositioning of the argument might therefore provide an account of canons which could actually serve to justify the cultural position of canons in the first place. At the same time, it might also serve to demonstrate the need to distinguish between different canons, that is, to clarify the relationships already existent between differing canonical forms.

Rather than perceive this logic as a justification for colonialist domination or for one canon's reign over another, the imposition of a particular canon upon other canons and canonically-formed cultures could actually present an interesting though complex vantage point from which to revision the problem of the canonical form and its relation to violence. For example, we might begin by looking into the myriad forms of resistance to particular canonical cultures that arise from within any given society, and indeed from within the same canonical form (e.g., with typical "heretical" movements). As Smith has already indicated, postcolonial theory, as only one example of this type of resistance, becomes a genuinely visible vantage point from within a canonical-culture-an embedded position from which to critique the canonical form.

It is no surprise moreover that postcolonial theory in particular has often allied itself with a deconstructionist philosophical framework in an attempt to dismantle the canonical forms of power that have exerted control over their cultures. Such theories inquire whether there is a dynamic at work in the desire for canonicity which functions as an "imperialist assimilation of the Other" for which we must now give an account. ${ }^{22}$ To invoke a postcolonialist critique in such a fashion is not a rhetorical or co-incidental 
strategy, as Smith has already demonstrated. Rather, it is one that highlights "marginal" knowledges that appear to be "non-canonical" and that are other than the ethnocentrism of any given canon (akin to the production of "western knowledge") because they interpret already-existing canons differently, with an ear to the violences with which they are either complicit or opposed. ${ }^{23}$

Hence, following Smith's appropriation of postcolonial theory, we could state that the canonical form in effect does promote a certain violence of introducing a fundamental division enacted by a monotheistic worldview, though not one that can simply be replaced or discarded. To see the validity of the canonical form in this way, we must first explore a fuller exposition of the "violence" introduced through canons, which in many ways has only served to arouse suspicion regarding the overt imposition of particular canons upon others. ${ }^{24}$ As canons are a necessary part of all cultures, however, they are not so easily either dismissed or deconstructed.

As will become clear in the analysis of the work of both Jan Assmann and René Girard which follows, by focusing upon the differences within the canonical form itself we will perhaps find a way through this apparent impasse, as well as a more lucid account that might serve to highlight the extreme political relevance of canons and of the Judeo-Christian scriptures in particular.

\section{Jan Assmann on the canon}

The initial consensus reaction to Sigmund Freud's later work Moses and Monotheism was that it was a speculative exposition of an almost absurd claim, that 
Moses was in fact an Egyptian and it was a repressed version of Egyptian monotheism that he revived and propagated in what was to become the Judaic form of faith. ${ }^{25}$ This initial scholarly reaction, however, subsided with time and gave way to a growing interest in Freud's work by philosophers, critical theorists and psychoanalytic schools of thought which not only embraced his work on Moses but saw it as a exemplary forerunner of contemporary cultural studies. ${ }^{26}$ One of the most significant, and recent, contributions to this large body of work has come from the Egyptologist Jan Assmann, whose work on Freud, Moses, and any alleged Egyptian ties has actually led him to reconsider the role which the canonical form plays in formulating a cultural-religious worldview - that is, its role in terms of creating historical representations and repressing desire (its latency). Assmann, for his part, has indeed constructed a more developed and more encompassing speculative system of his own, one that expands beyond Freud's project in order to depict specifically the role of canons in introducing a particular cultural and ideological violence of division within a given culture.

Assmann's redefinition of the Freudian project owes an obvious direct debt to Freud's work on Moses, although he also takes a substantially nuanced position toward it. According to Assmann, the revealing of the centrality of the canonical form to western religious and political identity has been a project of the "unthought" which need not arise from beneath the surface of the text, as Freud himself sought to indicate through his depiction of the "unconscious" of a text. This is the case for Assmann because texts dealing with historical representations, exemplified but not limited to the canonical form, actually reveal their truth on the surface. 
What Freud unearths and dramatizes as a revelation is not the historical truth, but merely some theoretical constructs that turn out to be superfluous. The truth can be found in the texts themselves. They speak of memory, remembrance, forgetting, and the repressed, of trauma and guilt. In order to uncover this network of meanings we have no need to practice the hermeneutics of distrust; nor need we read these texts against the grain. We need only listen to them attentively. $^{27}$

In contrast to Freud, he undertakes what he terms as a "mnemohistory," a study of the past not as it historically happened but as it is remembered by the texts themselves. The task of such a study is to listen to the text in such a way as to unveil any ideological script which unfolds in the narrative, not to dig beneath it for one presumed to be repressed. This is actually a process, he states, which intends on getting behind the "mythical elements" embedded within traditions themselves. Any history passed through a tradition is already a myth, while still yet maintaining a sense of historicity once it is "remembered, narrated, and used." 28 And in return, this discourse consisting of myth, once materialized as tradition, reproduces itself through its subjects. ${ }^{29}$ As we will see, Assmann reads Freud in this manner precisely in order to dislodge what he sees as the ideological script of monotheism presented in its canonical Judaic form, although in the end he might not be as free of canonical forms as his work seems to suggest.

For example, Assmann contends that the book of Deuteronomy contains theories of individual, collective and cultural memory. It confronts the Jewish people with the presence of a "counterfactual" memory and truly issues an imperative: they are called to 
remember a "framework" outside their present reality (e.g. recalling nomadic life in the midst of the promised land, or hunger in the midst of abundance, etc). This task is given to the people of Israel to keep "present to the mind a yesterday that conflicts with every tomorrow." ${ }^{30}$ The presence of counterfactual memory arises not only from the consolidation of forty years of memory as a mnemonic technique, but as closely bound to the monotheistic conception of revelation, especially since both manifest characteristics of an "extraterritorial" nature. That is, situating the divine granting of the Law in the wilderness becomes symbolic of nomadic wandering — an "extraterritorial" mandate which situates the Law as separate from any specific locality. As Assmann puts it, "this means that the laws that they are to remember and abide by are not the laws of the land, but the extraterritorial laws from Mount Sinai." ${ }^{31}$ This (re)defining of revelation and its relation to the canonical form is intended to expand Freud's project of perceiving writing as a nomadic exercise always displacing itself in order to reveal the "fuller" consequences of producing a written, sacred canon. ${ }^{32}$

In general, this reading of Freud allows Assmann to complete a reformulation of the canon itself - to see the desire for canonicity as a form of "counter-religion" that bears a constantly displaced revelation. ${ }^{33}$ "Counter-religions," as the name implies, seek to counter already existing religious trends by positing a "counter-history" of their own, one always set in motion by and thereby inherently connected to an established canonical text. These counter-histories aim to distort the self-image, identity, and memory of their adversary, offering their own "official" version of these constituent features through the instantiation of the canonical form. ${ }^{34}$ For Assmann, history in any form, including the canonical, becomes mythical again once it is "remembered, narrated, and used", thus 
providing a baseline ideological usage for itself, though not actually serving to negate the historicity of its account. ${ }^{35}$ Even an "imagined community" based upon a canonical foundation (to appropriate Benedict Anderson's celebrated phrase) can accurately represent history though it functions politically in a polarized and polarizing ideological manner. ${ }^{36}$ Again, all normative canonical forms are inherently intertwined with the political landscape in which they originate.

Assmann, through recognizing the pivotal role which an Egyptian monotheism played in forming the Israelite religion, establishes a structural parallel between two poles: revelation which is itself bound by the processes of the canonical (e.g. characterized by remembering, progression and a monotheistic or "Mosaic distinction" between true and false), and translation, which remained more ancient and bound to an oral culture (e.g. characterized by forgetting, regression and a polytheistic worldview). ${ }^{37}$ As this tension outlines, Assmann links revelation and canonization as fundamentally intertwined projects, since religions based on a written revelation (and not simply the monotheistic ones) "are all founded on a corpus of canonical writings and thus on a highly authoritative codification of memory. To belong to such a religion calls for this codified memory to be accepted and taken to heart. Evidently, the importance of the codification and canonization of memory is linked to the structure of the revelation. All revealed knowledge is by definition knowledge of something outside the world." 38

In this manner, faith becomes equated with memory and, thanks to Freud, an "inner spiritual guide" viewed as a progression over an antiquated desire for natural evidence once sought so heartily to justify religious belief. For Assmann, the decisive point remains the internal split in the subject brought about by monotheism's claims to 
divide reality into true and false, a split which renders the human heart itself subject to the dual traumas of desiring to be at home in the world (its pagan element), but also being told to reject and forget the false idols of paganism (its monotheistic side). ${ }^{39}$ It is also a division of the world brought about by the canonical form itself and is as such instrumental to certain political and ideological scripts.

At the end of the discussion of Freud's role within cultural canonical analysis, then, we are left with a de-centering of the trauma of monotheism, locating it not in the "Oedipal deep structure of the human psyche, but in the Mosaic distinction between true and false" that the canonical introduces into culture. It could only be enacted perpetually because it is grounded as revelation and in a very literal sense runs parallel to the sovereign's legitimation of power through recourse to a divine (transcendent) mandate. ${ }^{40}$ The binary divisions introduced by the "Mosaic distinction", in Assmann's view, begin to perform what will become a "monotheizing" tendency of the canonical form. As we have seen already in the cases of Schwartz and Smith, the canonical work introduces a fundamental division into culture, one which in effect could be said to generate a system of cultural significations and thereby create the apparently "non-canonical" or marginalized elements upon its fringes.

Though all of this attests to the canonical form's ability to generate cultural norms, our focus on the "return of the repressed"or a resurgence of the marginalized within (at times even seemingly against) canonically instituted divisions can help us to discern the cultural role of canonicity on a whole new level (as with its postcolonial reading by Smith). The canonical form, as it were, is often said to "forget" the heretical and/or apocryphal texts only to face their reemergence later, often during periods of 
religious renewal — an acknowledgement that is Assmann's strongest claim concerning polytheism's relation to monotheism. ${ }^{41}$ Functioning as signifier for an entire culturalsymbolic system, the canonical form produces a context that could be said to perform some degree of violence upon the marginalized elements otherwise excluded from representation.

This line of argumentation has been at the heart of several criticisms concerning Assmann's work as a whole, and which he addresses in his more recent work Of God and Gods. ${ }^{42}$ Noteworthy in this regard is the criticism offered by then Joseph Cardinal Ratzinger (now Pope Benedict XVI) of Assmann's alleged linkage between monotheism and violence, something which moved Ratzinger to remind those in the Catholic tradition of Christ's proclamation of peace, as well as to point out how other, non-canonical religions have brought various violences into the world as well. ${ }^{43}$

Responding to critics such as Smith and Ratzinger, who have seen his work as advocating something of a return to polytheism through the erasure of the true/false dichotomy, Assmann has nuanced his position by referring to the "latent monotheism within polytheism" as well as by offering a further distinction (beyond the simplified "Mosaic" one he offered earlier) between an intrasystemic violence (one translatable between cultures, and perhaps best exemplified by acts such as child sacrifice) and extrasystemic violence (one that is non-translatable, hence only serving as part of one's conversionary experience). Within this grid of violences, Assmann is able to critique monotheism's basic contention that it is opposed to intrasystemic violence while yet simultaneously giving rise to extrasystemic violence through its acts of (often forced) conversion or destruction. ${ }^{44}$ 
By later giving nuance to his position in response to his critics, Assmann has actually come to in part defend a monotheistic worldview by illustrating its indebtedness to a particular historical conceptualization of justice. In his view, the real contrast is one between an implicit theology (the cosmogony of a polytheistic worldview) and an explicit theology (the created order of the monotheistic one). ${ }^{45}$ Monotheism, from this perspective, becomes the inventor of "religion" as a concept as well as an embodied political practice, bringing a developed concept of justice from outside the traditional realm of (mythical-violent) religion into its inner self-definition. Again, canonical forms, religion and politics are inextricably linked together as the central identifiers of "culture," an originally western conceptualization that has since spread much wider since its "monotheistic" origins. The traffic among these three conceptual realms is therefore fluid. In this fashion, the monotheistic worldview is not only able to stand up as a critic of existing political structures, but is also capable of narrating a history based upon a divine notion of justice. ${ }^{46}$

In his view, Judaism was able to prevent itself from becoming indebted to a system of violence by refusing to universalize its historical claims, leaving them open to the processes of an eschatology never foreclosed within history and thereby also maintaining justice as an always open horizon against which all ("righteous") religious acts are formed. ${ }^{47}$ By this route of recirculation around his most analyzed concepts, Assmann comes very close to espousing a similar claim made in the last century by Walter Benjamin concerning the relation of the messianic to a divine and bloodless violence. By such means, Assmann is also able to denounce any religion associated with manifest violent forms and to declare that the "power of religion rests on nonviolence." 48 
The "weak form of truth" espoused here is a less-violent or even non-violent appeal to be sure, one coupled with its basic position as a counter-force to political power. This can be found at the origins of all monotheistic, canonical claims, according to Assmann, though the history of their reception has often proved anything but non-violent.

It is striking, however, that Assmann's clarifications have themselves gravitated toward a reading of the non-violence at the center of the biblical canonical framework. This brings his position into sharp relief against the backdrop of opinions already formed concerning his work. One of the large conceptual problems here, of course, is that there is a significant difference between non-violence and less violence. As Smith claims, canons are inherently violent, and this would be a stark challenge to Assmann's proposal of a non-violent core to the western monotheistic canon-if such a thing could even be said to exist.

In order to sift further through such complex problems and as an extension of where Assmann's arguments may ultimately lead, I turn to the work of the French literary theorist René Girard in order to clarify the distinctions of the canonical form in relation to violence and to analyze how the monotheistic canon might be said to reject or work beyond any extrasystemic violence still attached to its name.

\section{René Girard on violence in different canonical forms}

Deepening an account of the canonical form can be performed in two ways. On the one hand, it can be done by pursuing the foundations of the canonical form itself (its canonicity) which, in turn, can be seen to ground necessary cultural distinctions and as 
such allow us to see how a necessary violence could be possible as a sign of cultural identity, albeit one that remains relatively "bloodless." On the other hand, one could (as Assmann does) distinguish the types of canonical violences by opening our horizon of understanding toward the processes of canonicity themselves and thereby producing evidence of the differences between canons. Hence there are those canons which reveal violence and those which conceal it. By making these distinctions, we would here be developing a modified version of Freud's initial textual hermeneutic, which was intended to uncover what lies under canonical or normative texts, even if these "texts" are an individual's personal narrative. This textual hermeneutic has been extended furthest not only in the work of Assmann, but through the work of Girard.

In many ways, Girard's reading of cultural and religious texts is a reapplication of Freud's most basic insights, though it also shares in some of Assmann's contentions that the "truth" of the text can be read on its "surface."49 Consequently, Girard develops a fuller and deepened hermeneutic that combines fundamental insights from each: seeking what is repressed by reading what is already on the surface of the canonical text. This is developed as a key for understanding the actual forces and violences latent within the processes of canonicity.

By addressing the distinction between texts which reveal violence and texts which conceal it, I wish to move beyond the overly-simple appellations and condemnations of a general violence which is said to proceed from "monotheizing" canonical texts. Such designations, as we have seen with Schwartz, often fail to produce an adequate account of the cultural forces necessary to signify a social reality. They normally make with vague reference to a more primordial state of existence (e.g. polytheistic, multiple, etc) and fail 
to explain how any "primordial state" might be realized among canonical cultures as they are defined today. They also fail to mention how we are to realize politically such noncanonical configurations. In this sense, there needs to be more regard for discerning how a canonical-cultural index could actually be dismantled, discontinued, or converted, if such a thing would be desirable or even possible to do within a given cultural context.

What becomes apparent is the need to be more specific in defining the forms of violence performed by the "monotheizing" canonical work and to inspect the nature of the divisions it serves to create, deconstructing them when necessary in order to let justice proliferate. Accordingly, the contrast between the version of monotheism inherent to the canonical form and the potential for another version of a cultural-canonical foundation to arise in its place hinges upon how the distinction between the concealing of violence (as one form of the canonical) and the revealing of violence (as another form of the canonical) becomes more pronounced.

For Girard, as we will see, the contrast is one which illuminates an unconscious process of concealing the violence which gives rise to a particular civilization itself and which divides the canonical form into differing factions: those which testify against a particular violence and those which promote it, while both signify differing culturalcanonical distinctions between what is true or false.

Over the last few decades Girard's work has acquired something of a legendary status among certain scholars, especially those working within biblical or literary fields. Its ability to detail the intimate dynamics of desire and to overlay such descriptions onto a rich and vast literary heritage has drawn a great many admirers, though it has also been 
criticized for its sweeping claims. In many ways, it would not be too much to compare his "grand theory" to the Freudian corpus that preceded it.

Essentially, Girard's theory of the scapegoat - the seminal figure lying at the base of all societal formations - runs along these basic coordinates: the mimetic desiring of a given historical community must limit itself in order to function. As can be imagined, desires that are produced merely through the imitation of another person's desires (e.g., as can often be found in a "love triangle", or in advertising) over time begin to run amok and risk the destruction of the community (or the "institution", such as the family, a sport's team, a particular organization, etc). Rather than confront its own limitations directly, however, the community (often portrayed in literature as a "mob" or "crowd") simply and often ritualistically selects a scapegoat, either arbitrarily or through the future scapegoat's crossing of established cultural boundaries. Such a figure, once designated, will then have to be "sacrificed"- either ritualistically killed or exiled from the community - in order for the community to continue its normal state of things. In sum, the desire to deal with a crisis, itself a result of mimetic rivalry, generates a scapegoat who is dispatched and excluded from the community in order that the community might regain its sense of peace. In reality, however, such sacrifices are only a temporary alleviation; the core of mimetic desiring itself has not been directly addressed and thus this cycle must repeat itself again and again. ${ }^{50}$

In a reading that mimics Freud's essential insight concerning Moses' death, the memory of this violent event - so central to the community from which the myth originates and upon which the community itself is founded-is repressed in the mythical narrative and expunged from historical record, leaving only traces of its "truth" buried 
under the thin veil of a cyclical scapegoating process. The order now established within a society becomes mythically-based upon this falsified narrative, and peace becomes a temporary constraint upon mob violence - a matter of an impermanent alleviation, not an actual solution. ${ }^{51}$

Girard, for his part, chooses to focus upon the manner in which the mythical text hides the violence at the origins of society, in strong contrast to how biblical texts reveal the mechanisms of scapegoating and the accompanying logics of exclusion as a false means of achieving communal solidarity. ${ }^{52}$ By carefully unpacking literary-historical (and many mythological) texts alongside the canonical biblical ones, Girard aims for a project of demythologization. Yet this project also ends up restoring legitimacy to biblical texts through an illustration of their power to reveal the mechanisms of a mimetic desire that proves to be a means to the end of the cycle of mimetic violence. This power of the text, then, serves as a confirmation and legitimization of the canonical work in the Judeo-Christian tradition that eventually takes the side of the victim of mimetic violence (the excluded or sacrificed figure) while still maintaining the need for a canonical form. This alignment tends to redefine the relation of the canonical form in social-cultural terms over against the mythological canon which glorifies and justifies the violent founding acts of a society's order.

As one example of this mechanism, we might take Girard's analysis of the contrast between two founding myths of society. First, there is the Roman legend of Romulus and Remus, brothers who clash over the boundaries of the ancient city, with Romulus eventually killing his brother Remus. In this particular myth, there is no judgment passed by the narrative itself upon Romulus' actions; he simply becomes the 
founder of Rome. Next, there is the biblical story of Cain and Abel, where Cain kills his brother Abel out of jealousy at God's having bestowed his favor upon Abel. This story differs from the typical myth, in Girard's view, in that there is a negative judgment passed upon Cain as God sides with Abel's innocence. According to the biblical text, even though Cain goes on to found civilization, his actions are viewed as contrary to the canonical viewpoint - in absolute contrast to the Roman legend. ${ }^{53}$

Like Freud, Girard reads what would generally be considered as both "canonical" and "non-canonical" texts, especially as it is the varied, and often non-canonical texts that bear direct witness to this unconscious dimensions of violence inherent to the processes of mimetic desiring. ${ }^{54}$ Though Girard himself does not utilize this distinction as such between texts, it is important to note that his chosen texts, whether biblical or mythological, could be perceived as cultural-foundational, and, in that sense, always "canonical" in the culturally specific sense in which this essay uses the term. Indeed, his entire theory rests upon the manner in which ancient texts are said to be canonical, that is, constitutive of culture, and hence forming communal-ideological positions based upon the outcome of a particular mimetic rivalry.

While any direct reflection on canonical form seems absent from Girard's work, in fact it becomes the necessary link toward establishing an alternative process of historical memory apart from mythology. In a sense, any community which adopts a textually-based ritualistic prohibition upon mimetic violence and which seeks to end the cyclical processes of violence instituted through scapegoating is indeed paying homage to certain processes of canonicity: the ones that side with the excluded (and not merely marginalized) victim, as opposed to the mythological forms of canonicity that endorse of 
sacrificial violence. This is a careful distinction we must make with regard to Schwartz's critique, since Girard functions as the critic of her position insofar as he sees the Bible as fundamentally different from myth in its obsessive preservation of repressed narratives. ${ }^{55}$

At this point, Girard's distinction between canons becomes a central addition to our notion of canonicity, as it contains the potential for either an obsessive recording of a particular, repressed history (viewing the canonical as an attempt to do justice to the memory of an excluded people) or an obstruction of the violent truth behind the narrative (viewing the canonical as a legitimization of a particular dominant and exclusory ideology). At its core, then, the canonical form either exposes or conceals the violence at the center of human desiring. Either way, though, it is a process essential to social collective formations as we witness them in our world today.

Canonicity is thereby further defined through these insights as itself being a mimetic structure which responds to a crisis and then follows either a "truthful" relating of the actual processes of mimetic desiring, or a "falsified" relating which seeks to cover over its literal truth. The former definition, for its part, would seem to open us toward the foundation of an ethics, whereas the latter would open directly onto the field of ideology.

The formulation of canonicity is in fact the juxtaposition of an ethically less (but not non-) violent canon, wherein the powerless are allowed representation and the potential for justice to be done is increased, over against an ideological mythical one, wherein the powerless are scapegoated (not just marginalized) and perpetually at risk of being removed from society in general. The latter is a position that inherently opens the door to extra-systemic violences, as Assmann had earlier defined them. This emphasis elevates the principle of justice (seeking after the lesser violence) as a central 
hermeneutical key to reading canons and to mediating any conflict of methodologies when dialoguing over a canonical text. This also grants a space for representation not only of the excluded victim of an exclusive society, but also of the marginalized person within a particular non-exclusive community, bringing their right to assert subjectivity within a public forum created by the "truth-telling" canonical work. This responds to those who criticize Girard for being too simplistic or idealistic with regard to the distinctions drawn between different societies. It is also, I would add, one productive way to enact a "democracy of words" in the face of ongoing ethical violence. ${ }^{56}$

\section{Conclusions: Redefining the Canonical}

The canonical form, in this context, could thus be said to function as a dominator over its oppressed elements, continuously seeking their exclusion from representation and considering them as "unthinkable" within its "matrix of intelligibility." But the canonical could also be said to function as engaged with its marginalized elements, making them "thinkable" when necessary, even as central at times to the construction of any future cultural identity.

In this latter sense we can perceive the canon as capable of being aligned with a history of particular repressions, as potentially also bearing witness to them, and performing a certain justice to their memory when situations or events deem that it be so. Seeing this act of justice within a given canonical community, tradition, or text is essential if we are to move beyond the ideological suppression of marginal persons or histories. The very presence of a cry for justice within certain canons can function as a 
permanent fissure within any claims to totality or dominance which might otherwise arise. Rather than doing away with canonical forms and their binary division of reality, what such a reading of canonical forms offers us is a "division of division" itself, one starkly reminiscent of the Pauline attempt to turn the division of Jew and Gentile into one involving another level of flesh and spirit (Romans 8).

Drawing distinctions between the varying forms of violence present in our world thus assists us in forming a more complete picture of how different cultural formations arise based upon different notions of the canonical form generated, in turn, by different processes of canonicity. What emerges from this analysis is a powerful critique of social norms, differentiating those that derive from a truthful exposure of violence (siding with the excluded or repressed elements) from those that derive from a falsified justification of violence (siding with the dominant or exclusive elements). The potential to utilize this schema in discerning cultural conflicts is perhaps as vast as the implications for evaluating canonically-derived ethical paradigms.

In the formation of (ethical) subjects, produced by a given canonical form and therefore bound to certain historical processes of canonicity, the grounds for establishing the canonical form as a site of power are revealed most fully. It might seem paradoxical to suggest that the canonical form has the potential to preserve what appears as "noncanonical" (the echo of the marginalized), but that is the ethical import that follows from this analysis.

The stark contrasts of canonical presences within varying cultures, which each of these authors helps to illuminate, brings us to reconsider in what ways those who are excluded or marginalized might benefit from a greater understanding of canons and their 
constitutive power. The force of this redefinition of canons discloses a profound connection between canonical texts and the collective, cultural memories of repressed peoples who engage with such texts. The "revolutionary" tactic of assimilating canon to memory, a tactic which allows repressed memories and histories to be recognized as events which bring their own understanding before the canonical norm, must be seized upon and continuously repeated. ${ }^{57}$ The power of such negotiation between these two poles of narration is not only a service to the representation of those whose memories would otherwise quickly be forgotten in history, but also a model for reinterpreting the canonical texts themselves, opening them still further to new interpretations. This is also a task which theology must learn to take seriously, especially when performing its own acts of self-reflection.

Consequently an ethical dimension is revealed within the nature of the canonical form and the preservation of memory, one which elicits our theological response as communities of a sacred canon. ${ }^{58}$ The canonical form must not be harnessed to justify dominant oppressive cultures, unjust hierarchical forms, or other totalitarian powers, though it undoubtedly can be utilized to do so. Rather, it must be seen as a guarantor of the voices of the marginalized throughout history if it is to express itself as a site of truth, expose the falsity of a violence-oriented society, or become a site of revelation.

In a seemingly paradoxical inversion, the truthful canonical form actually has the potential to preserve the marginalized figure at its core through its fidelity to a sense of messianic justice that is always increasingly on the rise and always to-come. It opens itself to the voices of the marginalized within who do not threaten to undo the canon so much as to offer a possibility of less violence being done in the canon's signification of 
cultural subjects. The marginalized thereby serve as a constant disruption of any attempt to totalize canonical representations, a disruption that is starkly more or less welcomed by differing cultural viewpoints.

This is not to suggest, of course, that every apparent non-canonical representation is aligned in near perfect symmetry with a marginalized element, but only to suggest that a possibility lies open already within a given, particular canonical form. Eric L. Santner points out, in a critique of Assmann's position, that his "Mosaic distinction" is correct in a certain sense and yet misses the larger point: the trauma induced by this fundamental cultural division with which we identify is what enables us to relate to the trauma of the other and thereby greet them as our neighbors. ${ }^{59}$ This would undo canonical forms from within and render their divisions less divisive—a "division of division" itself.

Moreover, this paradoxical act of unveiling the unconscious of a text at the level of its conscious readability constitutes a self-reflexive movement wherein the canonical form stands "exposed" as it were, not as a prelude to its eventual decanonization, but as a gesture of self-reflexive understanding formed in relation to the desire for canonicity itself. Those who are subjects of the text and invested in the life of canons and their communities, who wish to stand in good faith with the canonical form itself, must begin to (re)read their own identities in light of the dynamisms generated not only between canonical forms and perceived non-canonical ones, but in the canonical form itself, a collection of multiple, dynamic desires therein united. Subjects of the text must likewise play host to a certain unveiling of their unconscious desires for (re)producing a text and for writing themselves into its narrative time and again —a decisive and consequential reworking of the roots of those theological accounts of confession normative to many a 
religious tradition. This dynamic process of interaction with the canonical form can thus evolve over time as a basic foundation for ethical paradigms, in order that a more proper interpretation of a particular canonical text might itself further evolve through time.

Beyond simply being an apologetic account of sacred scripture, the theological implications held in reserve within a study of canonicity and its relation to the canonical form are manifold and varied, produced by the foundational sense in which these processes can be said to generate culture and politics itself. Perhaps most acutely situated within this horizon for critique are implications for what a self-reflexive study of theology as a truth-telling, violence-exposing discipline might be. 
${ }^{1}$ This is, of course, the impetus for many popular stories today, including the Dan Brown's The Da Vinci Code (2003), the film Stigmata (1999) and even, one might suggest, the reason certain scholarly works become best-sellers. For example, take the work of Elaine Pagels and Bart Ehrman. See Elaine Pagels, Beyond Belief: The Secret Gospel of Thomas (New York: Vintage, 2004) and Bart D. Ehrman, Lost Scriptures: Books that Did Not Make It into the New Testament (New York: Oxford University Press, 2005).

${ }^{2}$ Such a desire is often present in the popularity surrounding the compilations of 'other' ancient 'lost' scriptures. Cf. Willis Barnstone, The Other Bible (New York: HarperOne, 2005).

${ }^{3}$ For a theological account of this term, see Louis-Marie Chauvet, Symbol and Sacrament: A Sacramental Reinterpretation of Christian Existence (trans. Patrick Madigan, SJ and Madeleine Beaumont, Collegeville, MN: Liturgical Press, 1995) 200f, as well as Raymond E. Brown and Raymond F. Collins, 'Canonicity' in Raymond E. Brown, Joseph A. Fitzmyer and Roland E. Murphy (eds.), The New Jerome Biblical Commentary (Englewood Cliffs, NJ: Prentice Hall, 1990) 1034-54.

${ }^{4}$ See, for example, Lee Martin McDonald and James A. Sanders (eds.), The Canon Debate (Peabody, MA: Hendrickson, 2002).

${ }^{5}$ Cf. Regina M. Schwartz, The Curse of Cain: The Violent Legacy of Monotheism (Chicago: University of Chicago Press, 1998) 5. 
${ }^{6}$ Cf. Jan Assmann, 'Translating Gods: Religion as a Factor of Cultural

(Un)Translatability' in Hent de Vries, (ed.), Religion: Beyond a Concept (New York:

Fordham University Press, 2008) 139-149.

${ }^{7}$ There is no doubt a certain affinity between these insights on a coming justice in relation to the canonical forms and the stated project of deconstructionism as found in the writings of Jacques Derrida, for example. Cf. Jacques Derrida's interview with Richard Rand, published as 'Canons and Metonymies' in Richard Rand (ed.), Logomachia: The Conflict of the Faculties Today (Lincoln, NE: University of Nebraska Press, 1992).

${ }^{8}$ The canonical, then, no matter whether of a secular or sacred nature, can be seen as inherently connected to its origins in a 'monotheizing' tendency to divide and organize culture accordingly. The 'Integrity of Reality', as James A. Sanders puts it, becomes defined by a book which could only be described as 'monotheizing' by virtue of its canonical form alone. See James A. Sanders, Canon and Community: A Guide to Canonical Criticism (Philadelphia: Fortress Press, 1984) 51. At the same time, the relationship between the literary and religious forms of the canonical begins to overlap further still and additionally to indicate a general pattern of the 'monotheizing' tendencies of canons as a whole, instituting their binary divisions upon the cultures they signify, and creating the 'non-canonical' as their obverse partner.

${ }^{9}$ Cf. Hector Avalos, Fighting Words: The Origins of Religious Violence (New York: Prometheus, 2005), Jack Nelson-Pallmeyer, Is Religion Killing Us? Violence in the Bible and the Quran (London: Continuum, 2005), J. Harold Ellens (ed.), The Dectructive Power of Religion: Violence in Judaism, Christianity, and Islam, 4 vols. (Westport, CT: 
Praeger, 2007) and A. Van Der Kooij and K. Van Der Toorn (eds.), Canonization and Decanonization (Leiden: Brill, 1998).

${ }^{10}$ Schwartz, The Curse of Cain, 141.

${ }^{11}$ Ibid., 116. See also the material on Assmann which follows.

${ }^{12}$ Ibid., 145-6.

${ }^{13}$ In essence, the canon's 'untranslatability' arises as a canon itself, by definition, defies its being incorporated into other cultures or religions. It stands alone in governing the culture/religion of a specific (and in this sense, limited) people.

${ }^{14}$ Ibid., 174-6.

${ }^{15}$ Mark S. Smith, The Memoirs of God: History, Memory, and the Experience of the Divine in Ancient Israel (Minneapolis, MN: Fortress, 2004). For Smith, this context is centrally fixed upon the similarities shared in the work of Jan Assmann and Ronald Hendel. On Assmann, see below; on Hendel, see his Remembering Abraham: Culture, Memory, and History in the Hebrew Bible (Oxford: Oxford University Press, 2005).

${ }^{16}$ Smith, The Memoirs of God, 151-2.

${ }^{17}$ Ibid., 123.

${ }^{18}$ Ibid., 158.

${ }^{19}$ Ibid., 169. Cf. similar arguments made in Mieke Bal, 'Religious Canon and Literary Identity' in The Mieke Bal Reader (Chicago: University of Chicago Press, 2006), David Lyle Jeffrey, People of the Book: Christian Identity and Literary Culture (Grand Rapids, MI: Eerdmans, 1996) and John David Dawson, Christian Figural Reading and the Fashioning of Identity (Los Angeles: University of California Press, 2002). 
${ }^{20}$ Mark S. Smith, God in Translation: Deities in Cross-Cultural Discourse in the Biblical World (Tübingen: Mohr Siebeck, 2008) 163.

${ }^{21}$ Ibid., 271.

${ }^{22}$ Gayatri Chakravorty Spivak, A Critique of Postcolonial Reason: Toward a History of the Vanishing Present (Cambridge, MA: Harvard University Press, 1999) 281.

${ }^{23}$ As has been common, in answer to the question of whether the marginalized can have a voice, or be represented in any sense, in the space of the canonical, the subaltern figure, as the pure 'heterogeneity of decolonized space', has been portrayed as the figure who cannot speak because the space of imperialist strategy does not allow it. Ibid., 310. The consequences of this suppression of what we might here call the "non-canonical (marginalized) voice' leads Spivak in fact to declare that 'We are driven to impose a homology of this Freudian strategy [a predication of a history of repression] on the Marxist narrative to explain the ideological dissimulation of imperialist political economy and outline a history of repression...' (285). Yet the insistence of the repressed, marginalized figure to achieve cultural and political representation is a necessary correlate to the ongoing historical acts of representation which otherwise progress without ceasing. The insistence that postcolonial critique calls for functions like 'the possibility of haunting', a tactic of the 'non-canonical', or repressed figure which proposes to be a constant disturbance to the canonical history, perhaps yet from within the canonical form: 'it is also true that for us the only figure of the unconscious is that of a radical series of discontinuous interruptions. In a mere miming of that figure, one might say that the epistemic story of imperialism is the story of a series of interruptions, a repeated tearing of time that cannot be sutured' (208). Nonetheless, despite its inability 
to be a complete narrative, the canonical is what gives rise to the historical; it is what details its form as well as its content. It is what sustains an ideological rigor and gives a people its identity. This point is essentially realized in projects which attempt to underscore the importance of merging a canonical tradition with a postcolonial perspective. For example, see R.S. Sugirtharajah, The Bible and the Third World: Precolonial, Colonial and Postcolonial Encounters (Cambridge: Cambridge University Press, 2001). The issue, then, concerns to what degree a particular canon 'haunts' itself from within, providing a means to index (rather than conceal or distort) the violence it performs upon its subjects.

${ }^{24}$ Two studies which take some of these fundamental dynamics of cultural division into account from a deconstructive position are Gil Anidjar, The Jew, the Arab: A History of the Enemy (Stanford: Stanford University Press, 2003) and Hent de Vries, Religion and Violence: Philosophical Perspectives from Kant to Derrida (Baltimore, MD: Johns Hopkins University Press, 2002).

${ }^{25}$ Sigmund Freud, Moses and Monotheism (trans. Katherine Jones, New York: Vintage, 1939).

${ }^{26}$ Cf. Sarah Winter, Freud and the Institution of Psychoanalytic Knowledge (Stanford: Stanford University Press, 1999). The general responses include, but are not limited to, the following interventions: Michel de Certeau, The Writing of History (trans. Tom Conley, New York: Columbia University Press, 1988); Yosef Hayim Yerushalmi, Freud's Moses: Judaism Terminable and Interminable, (New Haven, CT: Yale University Press, 1991); Jacques Derrida, Archive Fever: A Freudian Impression (trans. Eric Prenowitz, Chicago: University of Chicago Press, 1996); Richard J. Bernstein, 
Freud and the Legacy of Moses (Cambridge Studies in Religion and Critical Thought, Cambridge: Cambridge University Press, 1998); James J. DiCensio, The Other Freud: Religion, Culture and Psychoanalysis (London: Routledge, 1999); Eric Santner, 'Freud's Moses and the Ethics of Nomotropic Desire', in Renata Salecl (ed.), Sexuation (Sic 3, Durham, NC: Duke University Press, 2000; Jacob Taubes, The Political Theology of Paul (Cultural Memory in the Present, trans. Dana Hollander, Stanford: Stanford University Press, 2004), as well as Assmann's many interventions, as we will see in what follows. ${ }^{27}$ Jan Assmann, Religion and Cultural Memory: Ten Studies (trans. Rodney Livingstone, Stanford: Stanford University Press, 2006) 51-2.

${ }^{28}$ Jan Assmann, Moses the Egyptian: The Memory of Egypt in Western Monotheism (Cambridge, MA: Harvard University Press, 1998) 14.

${ }^{29}$ Ibid., 9-10, 16-7.

${ }^{30}$ Assmann, Religion and Cultural Memory, 53.

${ }^{31}$ Ibid., 53.

${ }^{32}$ This transitional phase toward an 'extraterritorial nature' of the Law is also able to underscore a qualitative difference between revelation and canonization, two events now essentially forever intertwined. As David Weiss Halivni articulates it: though 'Moses received the Torah at Sinai; the people of Israel received a canon in Jerusalem'. See his Revelation Restored: Divine Writ and Critical Responses (London: SCM Press, 2001) 85. This pivotal difference serves as well to highlight their intended relationship as an ideological interpretation of the Mosaic event, forever (re)construed for political purposes: 'The covenant of Sinai was realized by means of Ezra's canonical Torah; thus Ezra's canon received retroactively a Sinaitic imprimatur' (85). The legitimacy of the 
canon was fabricated upon an original revelatory event mired in Mosaic tradition and now intricately interlaced with it. This is to say that even though this historical difference is sufficient to produce a gap of some considerable significance, it is the mutual intertwining of the two concepts, and the fabricated proximity between them, which was to dissolve any conceptual difference and instead establish a unified scripture.

${ }^{33}$ Assmann, Moses the Egyptian, 170.

${ }^{34}$ Ibid., 33. Cf. Gerdien Jonker, The Topography of Remembrance: The Dead, Tradition and Collective Memory in Mesopotamia (Leiden: Brill, 1995) 26.

${ }^{35}$ Assmann, Moses the Egyptian, 14.

${ }^{36}$ Benedict Anderson, Imagined Communities: Reflections on the Origin and Spread of Nationalism (Rev. ed., London: Verso, 2006).

${ }^{37}$ Assmann, Moses the Egyptian, 3, 147. Cf. the comments on orality in Walter J. Ong, Orality and Literacy: The Technologizing of the Word (London: Routledge, 1982).

${ }^{38}$ Assmann, Religion and Cultural Memory, 54.

${ }^{39}$ Ibid., 58-9. For Assmann, one of the greatest historical 'truths' to emerge from this Freudian reading of religious origin is how the Jews themselves were, at the point just before the Exodus, a profound 'return of the repressed', a version of Amarna (King Akhenaten's) monotheism which was censored and erased from Egyptian cultural memory by force shortly before Moses' era: 'What could be more obvious than to declare Moses the disciple of Akhenaten? We might almost imagine that the two are identical' (59). Moses, in turn, came to represent a repressed memory of the Egyptians, one which met with their 'violent defense mechanisms' captured in the biblical account (61). ${ }^{40}$ Ibid., 62. 
${ }^{41}$ Petra Bahr, 'Canon/Canonization' in Kocku von Stuckrad (ed.), The Brill Dictionary of Religion (vol. 1, trans. Robert R. Barr, Leiden: Brill, 2006) 252.

${ }^{42}$ Jan Assmann, Of God and Gods: Egypt, Israel, and the Rise of Monotheism (Madison, WI: University of Wisconsin Press, 2008).

${ }^{43}$ Joseph Cardinal Ratzinger (Pope Benedict XVI), Truth and Tolerance: Christian Belief and World Religions, trans. Henry Taylor (San Francisco: Ignatius Press, 2004) 210-230. ${ }^{44}$ Assmann, Of God and Gods, 30ff. This reading, of course, runs in stark contrast with Ratzinger's attempt to diminish both the intra-and extra-systemic violence said to stem from Christianity's core.

${ }^{45}$ Ibid., 59 and $62 \mathrm{ff}$.

${ }^{46}$ Ibid., 75 and 22.

${ }^{47}$ Ibid., 111.

${ }^{48} \mathrm{Ibid} ., 145$. On Benjamin's working of the relationship between messianism and violence, see his 'Critique of Violence' read against the backdrop of his 'On the Concept of History', Selected Writings (eds. Howard Eiland et al., Cambridge, MA: Belknap, 2004-2006). Assmann himself alludes to Benjamin, though only in the brief context of his remarks concerning the different forms of violence experienced in our world (Assmann, Of God and Gods, 142ff). On Benjamin's famous 'weak messianic force' being co-opted theologically, see John D. Caputo, The Weakness of God: A Theology of the Event (Bloomington, IN: Indiana University Press, 2006)

${ }^{49}$ Cf. René Girard, Things Hidden Since the Foundation of the World (trans. Stephen Bann and Michael Metteer, Stanford: Stanford University Press, 1987) book 3. 
${ }^{50}$ Cf. René Girard, I See Satan Fall Like Lightning (Maryknoll, NY: Orbis, 2004) 19-31, $71-81$.

${ }^{51}$ The social implications of such a perspective are worked out quite emphatically in Gil Bailie, Violence Unveiled: Humanity at the Crossroads (New York: Crossroad, 1995) and James Alison, Raising Abel: The Recovery of the Eschatological Imagination (New York: Herder \& Herder, 1996).

${ }^{52}$ Ibid., $3 \mathrm{ff}$.

${ }^{53}$ See René Girard, The Scapegoat (trans. Yvonne Freccero, Baltimore, MD: Johns Hopkins University Press, 1989) 88-94.

${ }^{54}$ René Girard, Violence and the Sacred (trans. Patrick Gregory, Baltimore, MD: Johns Hopkins University Press, 1977) 143ff.

${ }^{55}$ This, of course, still leaves open the question of whether or not this tendency in Girard's depiction of the uniqueness of the Judeo-Christian canon is peculiar to that tradition alone. Girard has recently, it should be said, attempted to deal with other nonwestern religious narratives, evaluating them along such lines as suggested here in his Sacrifice (trans. Matthew Pattillo and David Dawson, East Lansing, MI: Michigan State University Press, 2011). See also the expansion upon Girard's theory specifically in relation to the history of sacrifice within Christianity in Mark S. Heim, Saved from Sacrifice: A Theology of the Cross (Grand Rapids, MI: Eerdmans, 2006).

${ }^{56}$ This theme in Girard's work is explicitly linked to the concept of canonicity in the work of James E. Brenneman, Canons in Conflict: Negotiating Texts in True and False Prophecy (Oxford: Oxford University Press, 1997), where the canon's applicability to life becomes intertwined with the processes of canonicity itself. The range of such a 
process is thus broadly defined: 'Canonical process thus began before the formal closure of the canon and continues right up to the present hour' (23). Following Girard's thesis, though often appropriating it as an indirect sub-current throughout his study, Brenneman portrays the canon as a 'limiting hermeneutic paradigm' conceived in order to attempt to contain the chaos which ensues from the manifestation of a multiplicity of intertextual readings (27). Unlike the ritualistic scapegoat mechanism which attempts to contain chaos by recreating a sacrificial victim and thus generating its own canonical text, the biblical canon does contain the chaos, by siding with the victim who is otherwise erased by the founding violence of myth. Positing this distinction places us in a position to state another crucial feature of the 'truthful' canonical work: it is always the work of the 'truthful' canonical text to deconstruct its own meaning, as Brenneman points out by highlighting the significance of contradictory prophetic passages (13ff). Here, we see that the biblical canon is a performative work, 'a book of conflicting words' which 'models for us first principles in communal negotiations', an ethical first principle (79). Canonical criticism, then, and from this viewpoint, could be read as a reminder of the vulnerability encountered during the times of social and political crises which gave, and give rise to the canonical in the first place and which remind us of the priority of the marginalized in determining the location of an ethical paradigm. This is to demonstrate a 'democracy of words' in the face of ethical violence and to perform a nonviolent act on behalf of the victim (139-40). Beyond this, and in regards to Girard's critics, such as John Milbank, among others, see the analysis offered in Frederiek Depoortere, Christ in Postmodern Philosophy: Gianni Vattimo, René Girard and Slavoj Žižek (London: T \& T Clark, 2008) 84ff. 
${ }^{57}$ Cf. Delwin Brown, Boundaries of Our Habitations: Tradition and Theological

Construction (Albany, NY: State University of New York Press, 1994) 150.

${ }^{58}$ A significant amount of work has already been done on the ethical realms of memory, but which is in need of being juxtaposed with the implications of the canonical. See, for example, Edith Wyschogrod, An Ethics of Remembering: History, Heterology, and the Nameless Others (Chicago: University of Chicago Press, 1998). From a theological context, see also Flora A. Keshgegian, Redeeming Memories: A Theology of Healing and Transformation (Nashville, TN: Abingdon, 2000).

${ }^{59}$ Eric L. Santner, 'Miracles Happen: Benjamin, Rosenzweig, Freud, and the Matter of the Neighbor' in Slavoj Žižek, Eric Santner and Kenneth Reinhard (eds.), The Neighbor: Three Inquiries in Political Theology (Chicago: University of Chicago Press, 2005) 1089. 